\title{
Human or not? Political rhetoric and foreign policy attitudes
}

\author{
Stephen M. Utych (D) \\ Boise State University, Boise, Idaho, USA \\ Corresponding author. Email: stephenutych@boisestate.edu
}

(Received 13 January 2020; revised 4 May 2020; accepted 4 August 2020; first published online 14 January 2021)

\begin{abstract}
When the United States intervenes in foreign countries, the lives of both foreign combatants and foreign civilians are put at risk. I examine two rhetorical strategies, the use of sanitized and dehumanizing language that can influence the public's support of foreign intervention. In the context of foreign policy, sanitized language operates by obscuring casualties of war, while dehumanizing language operates by devaluing the lives of groups of individuals. Drawing on data from two experiments, I find that sanitized language operates through creating less of an emotional reaction toward casualties of war, which causes individuals to adopt more hawkish foreign policy attitudes. I find that dehumanizing language also leads to more hawkish foreign policy attitudes, but, contrary to expectations, does not lead to increased disgust or anger toward dehumanized groups.
\end{abstract}

Key words: American politics; class and ethnicity; political psychology; race

The decision to use military force abroad is often a difficult political decision. The use of force has serious life and death consequences for those involved in the conflict, and, with the rising use of drone warfare, foreign civilians or combatants are overwhelmingly the ones whose lives are put at risk. A majority of Americans typically report that the United States government should minimize the killing of foreign civilians in international conflicts (Mueller, 2003). In many instances, however, the killing of foreign civilians is an inevitable side effect of war. How, then, can those who support foreign intervention minimize the impact of these casualties on public opinion?

I argue that political elites can influence the attitudes of the mass public toward foreign civilian casualties of war through the rhetorical strategies they use to describe these casualties. In particular, I focus on how the use of sanitized and dehumanizing language can influence foreign policy attitudes among the public. Language that is sanitized serves to obscure the fact that a human being has died. This language denies traits to individuals that separate humans from non-living entities (Haslam, 2006). For example, elites can refer to "surgical pressure," to mean "air strikes" or "bombings," obscuring the fact that military action is being taken at all. By calling the action surgical, a high level of precision is implied, suggesting that only those persons targeted will feel the effects of this pressure. This language not only obscures the fact that military action is being taken, but also makes this action seem clean and precise, and omits any discussion of civilians. I expect that the use of sanitized language will increase support for military intervention, and decrease concern over civilian casualties of conflict, compared to language that is not-sanitized and discussed civilian casualties directly.

(C) The Author(s), 2021. Published by Cambridge University Press on behalf of the European Political Science Association. This is an Open Access article, distributed under the terms of the Creative Commons Attribution licence (http://creativecommons.org/licenses/by/4.0/), which permits unrestricted re-use, distribution, and reproduction in any medium, provided the original work is properly cited. 
Another strategy that can make foreign casualties more palatable is the use of dehumanizing language. Dehumanizing language is used to reduce human beings to animals or other lower level forms of life (Haslam, 2006). The use of dehumanizing language will not obscure death, but will increase the public's acceptance of the deaths of certain groups by presenting them as subhuman. I expect that the use of dehumanizing language against a foreign enemy will lead to increased support for military intervention, and an increased acceptance of killing the enemy.

\section{Ignorance is bliss? How Americans (do not) respond to foreign civilian casualties of war}

Americans do respond to casualties of war-when those casualties are American soldiers (Mueller, 1973). While this is not all-encompassing, there are a wide range of conditions under which Americans will become less supportive of war as military casualties increase (see Gartner, 2008 for a discussion). While a vast literature on American responsiveness to military casualties exists, comparatively little work has been done on how the American public responds to civilian casualties of war.

Research examining responsiveness to foreign civilian casualties of war suggests two things: (1) many Americans say that they wish to avoid foreign civilian casualties of war, but (2) actual foreign civilian casualties have a negligible impact on support for war. This was demonstrated during the first Gulf War, where a majority of Americans viewed civilian casualties as unacceptable, but did not demonstrate any response to events where actual casualties occurred (Mueller, 2003). In small-scale military events, Americans ignore considerably large amounts of foreign civilian casualties (Burk, 1999). Large pluralities of Americans support the use of force even with a large civilian death toll, and prefer to protect the American military over foreign civilians (Gelpi et al., 2009). Most Americans tend to put the welfare of other Americans above that of people from other nations (Page and Bouton, 2008).

Why do Americans not respond to foreign civilian casualty events? One explanation is that the public is simply not aware of civilian casualty events. This argument is compelling-major US news networks devote only a very small amount of time to civilian casualties of war (Aday et al., 2005). Even in the Iraq War, where civilian death tolls were especially high, the Western media tended to avoid reporting these incidents (Kuttab, 2007). The media also tends to defer to the White House's policy position on foreign affairs, which is unsurprisingly optimistic and does not focus on the risk to foreign civilians (Entman et al., 2009). When civilian deaths are reported, this is typically done in a distant, statistical fashion, which fails to induce a strong emotional response to the casualties (Slovic, 2007). Even when civilian casualties are reported, Americans may hold conflicting views on these casualties.

In most foreign policy operations, it is possible that the killing of foreign civilians can be viewed as a means to a noble end; ideally, we would like to avoid the deaths of civilians, but certain goals, such as the removal of an evil dictator, are worth that human cost (Mueller, 2000). This was especially clear after the events of September 11, when Americans were considerably more accepting of civilian casualties in the War on Terror, as the threat to American lives from terrorism was made very real (Mueller, 2003). Americans were generally supportive of the use of the atomic bomb on Hiroshima and Nagasaki, as they were viewed as a means to prevent an even greater death toll (Mueller, 1973).

\section{Sanitized language and foreign policy attitudes}

I examine two types of language that can be used to influence support for foreign policy intervention. The first is the use of sanitized language. This language is used to reduce human beings to machines or non-living objects (Haslam, 2006). The use of sanitized language denies 
Table 1. Treatment question wording (All responses are coded from 1-strongly disagree to 7-strongly agree)

\begin{tabular}{|c|c|c|}
\hline & Sanitized language & Non-sanitized language \\
\hline Mention of casualties & $\begin{array}{l}\text { The United States should do whatever it takes } \\
\text { to capture al-Qaeda leaders } \\
\text { (Mean: } 4.59, \text { SD: } 1.73 \text { ) }\end{array}$ & $\begin{array}{l}\text { The United States should do whatever it } \\
\text { takes to capture al-Qaeda leaders, even if } \\
\text { this leads to the death of civilians } \\
\text { (Mean: } 3.62, \text { SD: } 1.62 \text { ) }\end{array}$ \\
\hline Non-combatant targets & $\begin{array}{l}\text { When considering military action, the United } \\
\text { States should do everything possible to } \\
\text { minimize the elimination of non-combatant } \\
\text { targets } \\
\text { (Mean: } 5.54, \text { SD: } 1.67 \text { ) }\end{array}$ & $\begin{array}{l}\text { When considering military action, the United } \\
\text { States should do everything possible to } \\
\text { minimize the killing of foreign civilians } \\
\text { (Mean: } 5.95, \text { SD: } 1.12 \text { ) }\end{array}$ \\
\hline Collateral damage & $\begin{array}{l}\text { The United States does not do enough to } \\
\text { minimize collateral damage in war } \\
\text { (Mean: 4.58, SD: } 1.28 \text { ) }\end{array}$ & $\begin{array}{l}\text { The United States does not do enough to } \\
\text { minimize civilian casualties in war } \\
\text { (Mean: } 4.63, \text { SD: } 1.37 \text { ) }\end{array}$ \\
\hline
\end{tabular}

Bolded text indicates changes between sanitized and non-sanitized language groups.

individuals traits that are essential to human nature-these include characteristics such as vivacity, emotionality, and warmth (Haslam, 2006). Sanitized language should operate by creating feelings of indifference toward the lives of those whose deaths have been sanitized (Bandura, 2002; Haslam, 2006). Because of this, I expect the use of sanitized language toward casualties of war to lead to a lower negative affective response than non-sanitized language, and to lead to more "hawkish" foreign policy attitudes overall.

Sanitization of civilian deaths occurs often during war time. When the media reports on civilian casualties, it is often done with vague language, leaving open the possibility that those killed were not civilians, but enemy combatants (Entman, 2006). Reporting on civilian casualties also frequently frames civilian deaths as accidents, or side effects of war (Wheeler, 2002). Sanitized language frequently is seen as a way to justify conduct that is considered morally reprehensible (Bandura, 2002), and has been used to create the image of clean, surgical wars (Kuttab, 2007). Through the use of sanitized language, the impact of the deaths of foreign civilians can be minimized in order to increase support for foreign military intervention.

To determine how sanitized language impacts political attitudes, I conducted a question wording experiment, where I varied the use of language to describe foreign civilian casualties of war. This study was conducted in March 2014, using a sample of undergraduates at a private, Southern university. ${ }^{1}$ In this study, subjects were randomly assigned to one of two groups: a sanitized language group or a non-sanitized language group. Each group received three questions on their attitudes toward civilian casualties of war, and were then asked to what extent they felt upset about the statement they just read. The full text of the questions appears in Table 1. The results of this analysis are presented in Table 2.

Various types of sanitizations of casualties of war affect political attitudes. When casualties of war are sanitized by omission, individuals are nearly one point more likely, on a seven-point scale, to agree that the United States should take action to capture al-Qaeda leaders. Even though foreign civilian casualties are a consequence of war in foreign nations, the mention of these casualties makes individuals less likely to support an all-out approach to capturing terrorists. This is a common type of sanitization-elites can simply not mention the consequences of actions to obscure the fact that human lives will be lost.

On the non-combatant targets question, sanitization makes individuals less likely to believe that the US should do everything possible to minimize civilian casualties. Here, the use of sanitized language predicts a roughly $1 / 4$ point decrease in support for the statement. For the collateral damage question, there is no effect of sanitized language on attitudes toward casualties, or the

\footnotetext{
${ }^{1}$ Subjects completed the study in a laboratory on campus in exchange for course credit. As expected with a student sample, most subjects were aged $18-22$.
} 
Table 2. How sanitized language influences attitudes and emotional reactions toward civilian casualties of war

\begin{tabular}{|c|c|c|c|c|c|}
\hline & $\begin{array}{l}\text { Mention of } \\
\text { casualties }\end{array}$ & $\begin{array}{l}\text { Non-combatant } \\
\text { targets }\end{array}$ & $\begin{array}{l}\text { Collateral } \\
\text { damage }\end{array}$ & $\begin{array}{l}\text { Upset-mention of } \\
\text { casualties }\end{array}$ & $\begin{array}{c}\text { Upset-non-combatant } \\
\text { targets }\end{array}$ \\
\hline $\begin{array}{l}\text { Sanitized } \\
\text { language }\end{array}$ & $\begin{array}{l}0.88^{\star \star *} \\
(0.19)\end{array}$ & $\begin{array}{r}-0.28^{\star} \\
(0.16)\end{array}$ & $\begin{array}{r}-0.03 \\
(0.15)\end{array}$ & $\begin{array}{l}-0.45^{\star \star \star} \\
(0.12)\end{array}$ & $\begin{array}{l}-0.53^{\star \star \star} \\
(0.13)\end{array}$ \\
\hline Republican & $\begin{array}{c}0.12 \\
(0.10)\end{array}$ & $\begin{array}{l}0.04 \\
(0.08)\end{array}$ & $\begin{array}{c}-0.08 \\
(0.08)\end{array}$ & $\begin{array}{c}-0.07 \\
(0.06)\end{array}$ & $\begin{array}{c}0.00 \\
(0.07)\end{array}$ \\
\hline Conservative & $\begin{array}{r}0.26^{*} \\
(0.13)\end{array}$ & $\begin{array}{r}-0.21^{*} \\
(0.11)\end{array}$ & $\begin{array}{c}-0.16 \\
(0.11)\end{array}$ & $\begin{array}{l}0.04 \\
(0.09)\end{array}$ & $\begin{array}{c}-0.13 \\
(0.10)\end{array}$ \\
\hline Constant & $\begin{array}{l}2.49^{\star \star \star} \\
(0.21)\end{array}$ & $\begin{array}{l}6.44^{\star \star \star} \\
(0.18)\end{array}$ & $\begin{array}{l}5.34^{\star \star \star} \\
(0.17)\end{array}$ & $\begin{array}{l}2.77^{\star \star \star} \\
(0.14)\end{array}$ & $\begin{array}{l}3.98^{\star \star \star} \\
(0.15)\end{array}$ \\
\hline $\begin{array}{l}N \\
R^{2}\end{array}$ & $\begin{array}{c}288 \\
0.2039\end{array}$ & $\begin{array}{c}288 \\
0.0440\end{array}$ & $\begin{array}{c}288 \\
0.1087\end{array}$ & $\begin{array}{c}288 \\
0.0543\end{array}$ & $\begin{array}{c}288 \\
0.0765\end{array}$ \\
\hline
\end{tabular}

Table entries are OLS coefficients with standard errors in parenthesis.

Results include all respondents. Results are robust to including only non-Hispanic white respondents.

${ }^{\star} p<0.1,{ }^{\star \star} p<0.05,{ }^{\star \star \star} p<0.01$.

emotional reaction to these casualties. This could potentially be explained by the fact that the term collateral damage was used frequently in the first Gulf War to refer to the deaths of civilians (Bennett, 1994). This provides some evidence that political elites, when using sanitized language, are only able to do so until the sanitization becomes well known by the public.

Sanitized language should operate by creating feelings of indifference toward the target of that language, or through muting the emotional response (Haslam, 2006). To test this prediction, I asked subjects the extent to which they feel upset about the statements that they just read. In both the mention of casualties and non-combatant targets questions, ${ }^{2}$ those exposed to sanitized language reported that they were less upset about the statements than those who were exposed to non-sanitized langue. The effect is roughly half a point on a five-point scale for both questions. This serves to explain how sanitized language operates-it causes a weaker emotional response to a person than non-sanitized language, which leads to greater approval of policies that put those people's lives at risk.

Of course, this does not explain how emotional responses are working. It is possible that the sanitized language is serving to mute an emotional response, making individuals feel less upset. It is also possible, and perhaps likely, that non-sanitized language creates a stronger negative emotional response. The important factor here is the difference between sanitized and non-sanitized language.

To examine this effect further, I turn to a mediation analysis of emotional response on these two attitudinal questions, using Average Causal Mediation Effects (ACME) procedures (Imai et al., 2010). ${ }^{3}$ The results are presented in Figures 1 and 2. Feeling upset partially mediates the effect of sanitized language on attitudes in the mention of casualties question. Both the indirect effect of feeling upset and the direct effect of sanitized language are statistically significant predictors of belief that the US should do whatever it takes to capture terrorists. It is not surprising that there is only partial mediation, as this type of sanitization also provides less information than in the non-sanitized condition. The non-sanitized condition prompts subjects to think about civilian casualties of war, while the sanitized condition only has them think about "whatever it takes."

For the non-combatant targets question, the effect of sanitized language is completely mediated by how upset subjects are toward the statement. While there is an indirect effect of sanitized language causing individuals to feel less upset about civilian casualties, there is no remaining direct effect of sanitization. This suggests that certain types of sanitizations may operate more

\footnotetext{
${ }^{2}$ There was a similar, though substantively small, effect for the collateral damage question $(\beta=-0.23, \mathrm{p}=0.05)$.

${ }^{3}$ Sensitivity analyses for both sets of mediation analyses are presented in the Appendix.
} 


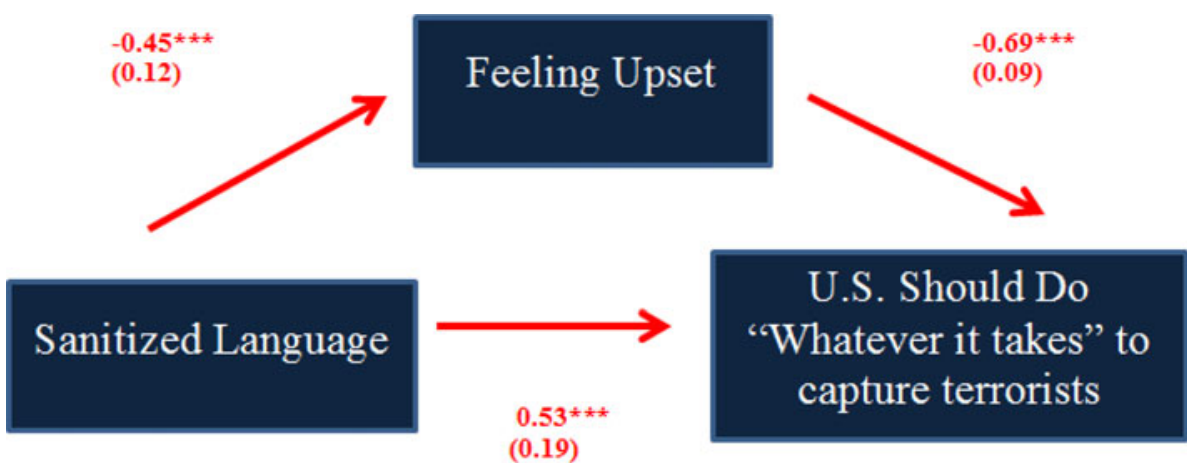

${ }^{*} \mathrm{p}<0.1,{ }^{* *} \mathrm{p}<0.05,{ }^{* * *} \mathrm{p}<0.01$

ACME: 306

Percent of Total Effect Mediated: $36.3 \%$

Figure 1. How feeling upset mediates the effect of sanitized language-mention of casualties.

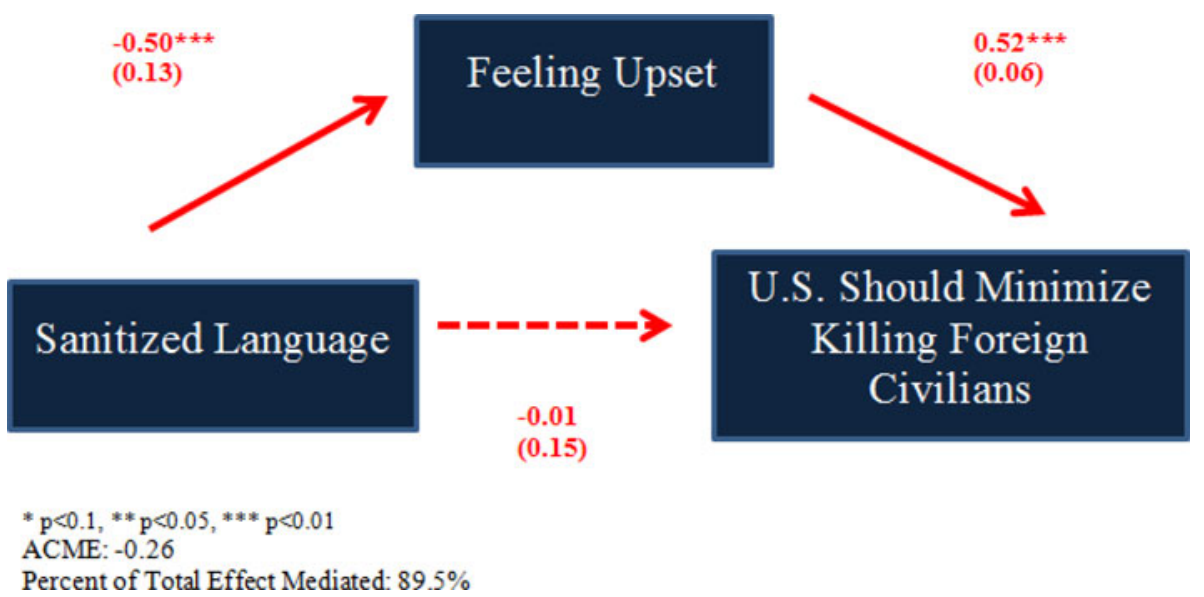

Figure 2. How feeling upset mediates the effect of sanitized language-non-combatant target.

effectively, as the "non-combatant target" sanitization appears to operate completely through muting the emotional response. In this case, sanitized language leads to a weaker emotional response toward the lives of the individuals being sanitized, which leads to less concern about their deaths. Taken together, these findings demonstrate that sanitized language can have a profound effect on attitudes toward civilian casualties of war-when language is sanitized, individuals are less concerned about civilian casualties and have a weaker emotional response to civilian casualties.

\section{Dehumanization of the enemy and foreign policy attitudes}

Dehumanizing language also serves as a way in which to deny basic human traits to other individuals. Dehumanizing language denies human beings traits that are uniquely human-traits such as the ability to reason that separate human beings from animals (Haslam, 2006). In this instance, the dehumanized group is denied the human trait of cognition (Tipler and Ruscher, 2014). Dehumanizing language, due to the denial of these human traits, is powerful in its own 
right. However, the relationship between dehumanization and negative attitudes toward outgroups is mediated by a negative affective response, either through disgust (Haslam, 2006), contempt (Esses et al., 2013; Louis et al., 2014), or both (Utych, 2018). Dehumanization denies important, human traits to outgroups, and creates an increased negative affective response to these dehumanized groups.

When an individual is dehumanized, they are viewed as less capable of realizing they are being treated poorly, which leads people to prefer harsher punishment of dehumanized individuals (Bandura et al., 1975). Dehumanized others are assigned low levels of worth, allowing individuals to justify punitive conduct toward those who are dehumanized by disregarding any negative effects of punishment (Bandura et al., 1996). In the instance of terrorism, the use of dehumanization against terrorists should lead to attitudes that accept harsher punishment of terrorists, and a devaluation of their lives.

Individuals tend to view groups that are more different than them as more animalistic (Leyens et al., 2000). Given that Middle Eastern terrorists do not share a race, ethnicity, or religion with most Americans, they should be easier for White Americans to accept as less than human that less socially distant individuals. Since shared identity may hinder dehumanization (Kteily et al., 2015), the lack of shared identity may change how White Americans view terrorists when they are dehumanized. In times of foreign conflict, dehumanization has been frequently used. During World War II, the Japanese were frequently depicted as animals in texts or on propaganda posters (Dower, 1986). Dehumanization leads to increased support of torture against terrorism detainees (Waytz and Epley, 2012). Waytz and Epley (2012) argue that socially distant groups, such as terrorists, are easier for individuals to dehumanize. These findings suggest that terrorists or foreign enemies may be especially easy for political elites to dehumanize, and for the mass public to accept the dehumanization.

To examine how language that dehumanizes terrorists influences political attitudes, I conducted an experiment that assigned subjects to read short vignettes. Subjects were assigned to receive either language that dehumanized terrorists, or non-dehumanizing language. ${ }^{4}$ This study was conducted in Summer 2014. Participants were recruited from Survey Sampling International's (SSI) survey panel. In total, 1106 subjects $^{5}$ participated in this portion of the study. Only non-Hispanic whites who are US citizens and do not report having an immediate family member serving in the military were recruited for this study. This is a nationally diverse, though not nationally representative, sample.

Here, subjects were randomly assigned to one of two groups: one that described terrorists using non-dehumanizing language, and one that described terrorists using dehumanizing language. The full vignette text presented to subjects is as follows:

\footnotetext{
${ }^{4}$ One could argue that the dehumanization treatment evokes more threat than the non-dehumanization treatment. In a post-treatment measure of self-reported fear, however, respondents in each report equal amounts of fear (3.07 for the control, 3.14 for the treatment, $\mathrm{p}=0.46$ ).

${ }^{5}$ There were significant issues with compliance. Many subjects read through the 83- or 89-word vignette very quickly. Of all respondents, 274, or about 24.7 percent, clicked through the page in $<10 \mathrm{~s}$. This corresponds to a reading speed of over $500 \mathrm{wpm}$, well higher than the average reading speed of $300 \mathrm{wpm}$. These subjects were excluded from analysis, as it is unlikely that they were able to process the information provided. Further, subjects were asked how believable they felt the vignette was on a scale of 0-100. I excluded subjects in the bottom 10 percent of believability in this analysis, or those who rated the text below 18 for believability. Believability ratings did not differ between the treatment and control groups (mean 55.0 for the control group, 55.3 for the treatment, $\mathrm{p} \sim 0.84$ ). This again suggests that subjects were not treated-while they may have read the text, they did not believe it, and it seems unlikely that the treatment was effective on these subjects. This strategy retains 623 subjects for analysis. Those retained were equally likely to be in the treatment group as those excluded (47.12 percent retained were in the treatment group, 49.9 percent excluded were in the treatment group, $\mathrm{p} \sim 0.39$ ). Because of the massive amount of non-compliance in this sample, it is best viewed as a diverse convenience sample. Results are robust for support military intervention including these respondents, and additionally for killing terrorists controlling for low believability ratings. Effect sizes become smaller in all cases, and do not reach statistical significance for the terrorists forfeit the right to life variable.
} 
Table 3. How dehumanizing language influences attitudes toward terrorism

\begin{tabular}{|c|c|c|c|}
\hline & $\begin{array}{l}\text { Support military } \\
\text { intervention }\end{array}$ & $\begin{array}{l}\text { Terrorists forfeit } \\
\text { right to life }\end{array}$ & $\begin{array}{l}\text { Kill terrorists rather } \\
\text { than try in court }\end{array}$ \\
\hline Dehumanization treatment & $\begin{array}{l}0.30^{\star \star *} \\
(0.11)\end{array}$ & $\begin{array}{l}0.26^{*} \\
(0.14)\end{array}$ & $\begin{array}{l}0.28^{\star *} \\
(0.12)\end{array}$ \\
\hline Republican & $\begin{array}{l}0.66^{\star \star \star} \\
(0.20)\end{array}$ & $\begin{array}{c}-0.18 \\
(0.25)\end{array}$ & $\begin{array}{c}-0.01 \\
(0.22)\end{array}$ \\
\hline Conservative & $\begin{array}{l}1.36^{\star * *} \\
(0.26)\end{array}$ & $\begin{array}{l}2.10^{* * *} \\
(0.32)\end{array}$ & $\begin{array}{l}1.57^{\star \star \star} \\
(0.28)\end{array}$ \\
\hline Constant & $\begin{array}{l}3.44^{\star \star \star} \\
(0.13)\end{array}$ & $\begin{array}{l}3.27^{\star \star \star} \\
(0.17)\end{array}$ & $\begin{array}{l}4.13^{\star \star \star} \\
(0.14)\end{array}$ \\
\hline $\begin{array}{l}N \\
R^{2}\end{array}$ & 623 & 623 & 623 \\
\hline$R^{2}$ & 0.1401 & 0.0910 & 0.0786 \\
\hline
\end{tabular}

Table entries are OLS coefficients with standard errors in parenthesis.

Data excludes any participant who read the five sentence treatment in $<10 \mathrm{~s}$, or rated the text in the bottom 10 percent of all subjects in terms of believability.

${ }^{\star} \mathrm{p}<0.1,{ }^{\star *} \mathrm{p}<0.05,{ }^{\star \star *} \mathrm{p}<0.01$.

Imagine now that the United States is considering a foreign military intervention as part of the War on Terrorism. Please read the following text from a supporter of intervention.

\section{Non-dehumanization treatment}

The United States must do whatever it can to stop terrorism around the world. If a country becomes a safe haven for terrorists, we are responsible for going in there and combating the threat. Over a decade ago, we made a commitment to catch terrorists, wherever they are, and we must not stop until we have accomplished that goal. These terrorists, these criminals, they do not deal in diplomacy. We are facing a serious threat, and we must take action to prevent it.

\section{Dehumanization treatment}

The United States must do whatever it can to crush terrorist cells around the world. If a country becomes a breeding ground for terrorists, we are responsible for going in there and exterminating the threat. Over a decade ago, we made a commitment to hunt down these wolves, wherever they are, and we must not stop until we have accomplished that goal. These terrorists, these creatures, they do not deal in diplomacy. We hate a rattlesnake in the garden, and we must go in and chop off its head.

Results of the analyses for this study are presented in Table $3 .^{6}$ When terrorists are dehumanized, individuals are about 0.30 points more likely to support military intervention against terrorists. This effect is about 22 percent of the effect of moving across the scale of ideology.

Further, those presented with dehumanizing language are also more likely than those who are not to believe that terrorist's lives are less valuable. Subjects were asked two questions related to the lives of terrorists. The first question asks to what extent subjects agree with the statement "When someone engages in terrorism, they have forfeited their right to life." Here, subjects in the dehumanization treatment are about a quarter of a point more likely than those who are not to agree with the statement. Subjects are also asked the extent to which they agree with the statement "The military should kill known terrorists, rather than capture them and try them in court." The effects here are similar, just over a quarter of a point on the scale, with those in the dehumanizing treatment more likely to agree with the statement. Taken together, this set of results suggests that individuals are more likely to be supportive of action against terrorists, and more likely to disregard the value of their lives, when they are presented with language that dehumanizes terrorists.

\footnotetext{
${ }^{6}$ All dependent variables in Table 3 are measured on a seven-point scale.
} 
Dehumanizing language should operate through increasing disgust or anger toward the dehumanized individual. I do not find evidence, however, that the dehumanization treatment led to increased feelings of either emotion. The mean levels of disgust were 4.24 for the treatment, and 4.26 for the control ( $\mathrm{p}=0.73)$, while the mean levels of anger were 4.21 for the treatment, and 4.13 for the control $(\mathrm{p}=0.30)$. While individuals do not appear to be responding to the dehumanization treatment with disgust or anger, the overall levels of these negative emotions are very high. ${ }^{7}$ This suggests that this mechanism may already be operating, and simply cannot be further activated by dehumanization.

While the effects of dehumanization on attitudes are small, this is in line with other studies using language manipulations to study dehumanization (Utych, 2018; Utych, 2020). Other factors certainly influence attitudes toward terrorists more than dehumanizing language, but there is a small effect, even on a group that is nearly universally loathed. Further, the high levels of anger and disgust toward terrorists suggest that they may already be dehumanized. Since these are the mechanisms through which dehumanization often operates (Haslam, 2006), it is unlikely that dehumanizing language may have a strong additional effect. Indeed, previous work has shown that political elites frequently talk about terrorists in dehumanizing terms (Utych, 2014), suggesting that this dehumanization of terrorists may be chronic.

\section{Summary and conclusions}

Sanitized and dehumanizing language both influence how individuals view foreign policy intervention and casualties of war. When presented with sanitized language, individuals were less concerned about civilian deaths in military interventions, and they reported lower feelings of concern about the deaths of civilians, which mediate the effect of sanitized language on attitudes. Dehumanization causes individuals to be more supportive of military intervention, and be more accepting of the deaths of terrorists, rather than their capture and trial.

This research has implications for scholars of public opinion. The language used to talk about political issues has an impact on public attitudes about these issues (Zaller, 1992). If war is often described in clean, sanitized terms, this should lead to increased public support of foreign conflict. If war is described in ways that dehumanize the enemy, this will also lead to an increase in public support. These two rhetorical techniques can both serve to minimize the cost of human life in war.

Of course, this study is not without limitations. The study on dehumanization had large issues with non-compliance of respondents, perhaps leading to underestimation of effect sizes. Additionally, it is hard to compare the effects of dehumanizing and sanitized language based on these results, given that the samples were quite different-a nationally diverse sample for the dehumanization study, and a student convenience sample for the sanitized language study. These studies also differed in mode, with students completing the study in a lab, while the nationally diverse sample completed the study online. Future work is needed to compare the relative effects of dehumanization and sanitization.

In the area of foreign policy intervention, the lives of foreigners are routinely put at risk. I find that the language used to discuss foreign intervention can have an important impact on political attitudes toward intervention. By using language that sanitizes casualties, or dehumanizes an enemy, political elites can garner increased support for military intervention. When the public reacts to casualties in foreign policy, it seems to matter not only what they learn, but what words are used to convey those messages.

Supplementary material. The supplementary material for this article can be found at https://doi.org/10.1017/psrm.2020.58

\footnotetext{
${ }^{7}$ For comparison, in an unrelated portion of the study, subjects were asked to report their level of disgust and anger toward illegal immigrants. Here, the mean level of disgust was 2.40 , and the mean value of anger is 2.67 .
} 


\section{References}

Aday S, Livingston S and Hebert M (2005) Embedding the truth: a cross-cultural analysis of objectivity and television coverage of the Iraq War. The International Journal of Press/Politics 10, 3-21.

Bandura A (2002) Selective moral disengagement in the exercise of moral agency. Journal of Moral Education 31, $101-119$.

Bandura A, Underwood B and Fromson ME (1975) Disinhibition of aggression through diffusion of responsibility and dehumanization of victims. Journal of Research in Personality 9, 253-269.

Bandura A, Barbaranelli C, Caprara GV and Pastorelli C (1996) Mechanisms of moral disengagement in the exercise of moral agency. Journal of Personality and Social Psychology 71, 364-374.

Bennett SE (1994) The Persian Gulf war's impact on Americans' political information. Political Behavior 16, $179-201$.

Burk J (1999) Public support for peacekeeping in Lebanon and Somalia: assessing the casualties hypothesis. Political Science Quarterly 114, 53-78.

Dower JW (1986) War Without Mercy: Race and Power in the Pacific war. New York: Random House.

Entman RM (2006) Punctuating the homogeneity of institutionalized news: abusing prisoners at Abu Ghraib versus killing civilians at Fallujah. Political Communication 23, 215-224.

Entman RM, Livingston S and Kim J (2009) Doomed to repeat: Iraq news, 2002-2007. American Behavioral Scientist 52, 689-708.

Esses VM, Medianu S and Lawson AS (2013) Uncertainty, threat and the role of the media in promoting the dehumanization of immigrants and refugees. Journal of Social Issues 69, 518-536.

Gartner SS (2008) The multiple effects of casualties on public support for war: an experimental approach. American Political Science Review 102, 95-106.

Gelpi C, Feaver PD and Reifler J (2009) Paying the Human Costs of War: American Public Opinion and Casualties in Military Conflicts. Princeton, NJ: Princeton University Press.

Haslam N (2006) Dehumanization: an integrative review. Personality and social psychology review 10, 252-264.

Imai K, Keele L and Tingley D (2010) A general approach to causal mediation analysis. Psychological Methods 15, 309-334.

Kteily N, Bruneau E, Waytz A and Cotterill S (2015) The ascent of man: theoretical and empirical evidence for blatant dehumanization. Journal of Personality and Social Psychology 109, 901-931.

Kuttab D (2007) The media and Iraq: a blood bath for and gross dehumanization of Iraqis. International Review of the Red Cross 89, 879-891.

Leyens J-P, Paladino PM, Rodriguez-Torres R, Vaes J, Demoulin S, Rodriguez-Perez A and Gaunt R (2000) The emotional side of prejudice: the attribution of secondary emotions to in-groups and out-groups. Personality and Social Psychology Review 4, 186-197.

Louis WR, Esses VM and Lalonde RN (2014) National identification, perceived threat, and dehumanization as antecedents of negative attitudes toward immigrants in Australia and Canada. Journal of Applied Social Psychology 43, E156-E165.

Mueller J (1973) War, Presidents, and Public Opinion. New York: John Wiley and Sons.

Mueller J (2000) Public opinion as a constraint on U.S. Foreign Policy: Assessing the perceived value of American and foreign lives. Presented at National Convention of the International Studies Association: Los Angeles.

Mueller J (2003) Police work or war? Public reactions to dates of infamy. Public Perspective 14, 31-34.

Page BI and Bouton MM (2008) The Foreign Policy Disconnect: What Americans Want From our Leaders but Don't Get. Chicago: University of Chicago Press.

Slovic P (2007) "If I look at the mass, I will never act": psychic numbing and genocide. Judgment and Decision Making 2, 79-95.

Tipler C and Ruscher JB (2014) Agency's role in dehumanization: non-human metaphors of out-groups. Social and Personality Psychology Compass 8, 214-228.

Utych SM (2014) Dehumanizing the cost of war: how politicians talk about death in the Iraq War. Paper presented at the 2014 Annual Meeting of the Midwest Political Science Association, Chicago.

Utych SM (2018) How dehumanization influences attitudes toward immigrants. Political Research Quarterly 71, 440-452.

Utych SM (2020) Race, dehumanization and the NFL anthem protests. Journal of Experimental Political Science doi: https:// doi.org/10.1017/XPS.2020.33

Waytz A and Epley N (2012) Social connection enables dehumanization. Journal of Experimental Social Psychology 48, 70-76.

Wheeler NJ (2002) Dying for "Enduring Freedom": accepting responsibility for civilian casualties in the war against terrorism. International Relations 16, 205-225.

Zaller JR (1992) The Nature and Origins of Mass Opinion. Cambridge: Cambridge University Press.

Cite this article: Utych SM (2022). Human or not? Political rhetoric and foreign policy attitudes. Political Science Research and Methods 10, 642-650. https://doi.org/10.1017/psrm.2020.58 